\title{
Total quality management applications in sports and an application on Kocaeli amateur sports club federation sports clubs
}

\author{
Ayşe Demir ${ }^{1, *}$ and Kürşad Sertbaş ${ }^{2}$ \\ ${ }^{1}$ Istanbul Aydin University, Faculty of Sport Sciences, 34295 Kucukcekmece-Istanbul, Turkey \\ ${ }^{2}$ Kocaeli University, Faculty of Sport Sciences, 41000 Umuttepe-Kocaeli, Turkey
}

\begin{abstract}
In this study, the quality management systems in sports clubs were handled specifically for amateur sports clubs and the perceptions of sports club managers regarding quality management systems were searched. The aim of the research is to determine whether the applications for total quality management in amateur sports clubs are implemented effectively and efficiently and to determine the precursors which have an impact on total quality management processes simultaneously. The scale developed by Özdemir (2015) was used to determine the perception of Total Quality Management in sports clubs as a measurement tool in the research. The survey sample is composed of 123 managers, including 4 female $(3,3 \%)$ and 119 male $(96,7 \%)$ volunteers who act as managers in the clubs operating under the Kocaeli Amateur Sports Clubs Federation and voluntarily respond to the questionnaires. Analyzes of the collected data using the total quality scale (Cronbach's Alpha: 0,970). It is found that amateur sports clubs are positive towards the applicability of total quality management processes, whereas amateur sports clubs are positive about the applicability of total quality management processes, it is predicted that managers have sports history $(\mu=4,022>\mu=3,98)$ The positive attitude towards the applicability of total quality management processes in the clubs was not the result of the managers being trained in sport management and quality system $(\mu=3.99>\mu=4,03)$.

Keywords: Total Quality Management, Amateur Sports Clubs, Quality in Sports ${ }^{1}$
\end{abstract}

\section{Introduction}

Quality and total quality management concepts are important concepts which are frequently discussed in today's world. By the effects of globalization the competition conditions are increasing day by day and in today's global markets, these concept which are about quality, process quality and total quality are important for both sustainability and profitability of each organization. Products and services quality is important not only for the organizations operating in the production sector but also for all the organizations regardless of the sector difference. Within this scope, organizational processes are being carried out with total quality understanding today. The main focus of total quality understanding is to make all processes related to knitting, both internal and external customer satisfaction, efficient, efficient and sustainable towards the objectives of the organization and aiming at continuous improvement in this process. In other words, total quality understanding is a

* Corresponding author: aysedemir@,aydin.edu.tr 
managerial strategy for today's organizations, and the most basic expectation in this process is to produce quality products, services and processes aimed at determined organizational goals and targets in a way that satisfies the demands and needs of the customers at the maximum level. The main focus is on this process. It is not only the organization's customers who are the customers of the products and services but also the employees who work in processes to bring these products, services and processes together with the customers at the same time.

Sports clubs are one of the most important actors in the sport sector. The quality levels of the outputs produced by sports clubs will increase in parallel with the satisfactory satisfaction of the activities carried out by the sports club stakeholders producing the sports service from the processes in the sports club. The concept of quality and quality systems in sports clubs are considered systematically, including the monitoring of sports services, the identification of problems related to the processes and the improvement of quality and feedback processes [1]. Regarding all processes carried out in a sports club; implementation of quality and quality management practices effectively, such as training processes, infrastructure activities, team work processes - will provide value to the sports clubs.

Quality is a concept which has different definitions with the reason that it is a concept that is handled by many different disciplines in the field of writing. In other words, there is not a generally accepted definition of the concept, but there are different definitions that explain the multidimensional nature of the concept. In the most basic sense quality relates to the quality of a product or service or a process, its predefined goals and its suitability for use [2]. According to another definition, the judgments reached for quality, products, services or processes [3]. Quality is the whole systematic process for approaching excellence in products, services or processes [4].

When the history of the concept of quality is examined, it is seen that the history of the concept is as old as the history of humanity. Even though there are considerable differences between the initial definitions of concept and the way the concept is handled and the framework of the present quality concept, quality is basically a concept held equal to aiming to be the best in every period.

The period of important and structural developments related to the concept of quality is the beginning of the twentieth century. At the beginning of the twentieth century, the most important reason for the importance of quality-oriented studies and researches is the spread of statistical thinking in everyday and economic processes.

The total quality management approach is based on the most basic understanding of all the qualitative steps in the historical process - leadership, scientific approach, team work, continuing education, responsibility, authority [5]. Total quality management is, in a sense, systematic for the focus of all organizational employees in order to help increase the efficiency of an organization at all levels and in all its processes [6]. If total quality management is implemented effectively and productively, it results in quality improvements in terms of process improvement, positive employee contribution and goals and targets in terms of all organizations. In this context, it is seen that the processes related to quality and total quality management are important when they are considered from the perspective of success oriented organizations such as sports clubs.

At the point of adopting total quality understanding in sports clubs, it is possible to identify the strengths of the clubs and to identify the weak points in the process. Through the quality management systems carried out in this context, it is seen that there is an increase in the organizational culture and team unity in sports clubs. It is important to integrate certain steps into existing systems at the point of applying qualitative systems in sports clubs [7];

- Strategic planning: identification of the institutional identity of the sports club, plans for the goals and targets and processes related to financial management 
- Internal procedures and system: planning external services to ensure the sustainability of the processes in the sports clubs, setting up internal procedures

- External relations: identification of activities and activities of sports clubs related to the public

- Organizational culture: organizing tournaments, organizations and similar activities to increase the team culture and team unity and spread the culture towards clubs

- Management structuring: to be systematized with the board of directors and other working committees to make total quality understanding sustainable as a managerial strategy

- Success: Adoption of total quality understanding, ensuring internal and external customer satisfaction, and continuous improvement approach spread to all processes, achieving success in sportive and economic sense.

Managers working in the management positions of sports clubs [8], at the point of making the implementation and sustainability of total quality management systems in sports clubs;

- Establishing the necessary trust environment in sports clubs to make quality management systems workable

- One of the key factors in the effectiveness of quality management systems is the adoption of team work by all process stakeholders. In this framework, one of the most important tasks of the managers is to strengthen the team working environment.

- To effectively manage processes to increase the motivation of sports club employees and to create internal customer satisfaction, which is the primary necessity of total quality management systems.

Another important aspect of sports total quality management is that, after the establishment of quality management systems, it is often necessary to develop and continually audit in parallel with quality management standards. At the point of development of quality management systems; determination of common goals, openness to innovation, dissemination of team work, determination of continuous improvement approach are important factors.

\section{Methodology}

\subsection{Aim of the Research}

The aim of the research is to determine whether the applications for total quality management in amateur sports clubs are implemented effectively and efficiently and to determine the precursors which have an impact on total quality management processes simultaneously.

\subsection{Research Method}

Quantitative research method is used in in this research and the research design is descriptive survey model. The research has been conducted on the managers of the clubs affiliated to the Kocaeli Amateur Sports Clubs Federation. At the beginning of the implementation period, the necessary permissions were obtained from Kocaeli University and Kocaeli Amateur Sports Club Federation and the application was implemented using face to face interview technique.

\subsection{Research Hypothesis}

$\mathrm{H}_{1}=$ the perception towards the practicality of total quality management is favorable in amateur sports clubs. 
$\mathrm{H}_{1 \mathrm{a}}=$ the perception towards the practicality of total quality management is not favorable in amateur sports clubs.

$\mathrm{H}_{2}=$ the managers of the sports club do have sports background is an antecedent on the favorable perception towards the practicality of total quality management in amateur sports clubs.

$\mathrm{H}_{2 \mathrm{a}}=$ the managers of the sports club do have sports background is not an antecedent on the favorable perception towards the practicality of total quality management in amateur sports clubs.

$\mathrm{H}_{3}=$ the managers of the sports club do have education about quality management is an antecedent on the favorable perception towards the practicality of total quality management in amateur sports clubs.

$\mathrm{H}_{3 \mathrm{a}}=$ the managers of the sports club do have education about quality management is not an antecedent on the favorable perception towards the practicality of total quality management in amateur sports clubs.

\subsection{Population and Sample}

The population of the research is the amateur sports clubs in Turkey. The sample of the research is composed of 123 managers, including 4 female $(3,3 \%)$ and 119 male $(96,7 \%)$ volunteers who act as managers in the clubs operating under the Kocaeli Amateur Sports Clubs Federation and voluntarily respond to the questionnaires.

\subsection{Data Collection Tool}

There are two data collection tools are used in this research. These are;

- Personal information form, is a form which measures participants' age, gender, occupation, duration of being a sports club manager, educational background, sports background (amateur or professional), education about sports management, education about total quality systems.

- Total quality scale is a scale developed by Özdemir (2015) for designating the perception of total quality management in sports clubs. The Cronbach's Alpha is calculated for the reliability of the scale and the Cronbach's Alpha of the scale is founded 0,970, which shows that the scale do have high reliability.

\subsection{Data Analysis Technique}

SPSS 22.0 is used for analyzing the data collected via the scales of the research. The reliability is measured by calculating Cronbach's Alpha. The descriptive statistics are calculated and the confidence level $\% 95$, the significance level $\mathrm{p}<0.05$ is considered during the analysis conducted for the research hypothesis.

\subsection{Premises and Restrictions}

The premises of the research are;

- Each question answered by the sample group is assumed to reflect its own individual considerations,

- It is assumed that the resources used for the questions in the questionnaire used as data collection tools are sufficient

The restrictions of the research are;

- Research is limited to data collection tools (scales).

- The findings of the research are limited to the population and sample of the research. 


\section{Findings and Discussion}

\subsection{Descriptive Statistics of the Sample}

Table 1. Descriptive Statistics

\begin{tabular}{|c|c|c|}
\hline & Frequency & Percentage \\
\hline \multicolumn{3}{|l|}{ Gender } \\
\hline Female & 4 & 3,3 \\
\hline Male & 119 & 96,7 \\
\hline Total & 123 & 100,0 \\
\hline \multicolumn{3}{|l|}{ Age } \\
\hline$<18$ & - & - \\
\hline $19-30$ & 10 & 8,1 \\
\hline $31-42$ & 46 & 37,4 \\
\hline $43-54$ & 37 & 30,1 \\
\hline $55-66$ & 25 & 20,3 \\
\hline $66<$ & 5 & 4,1 \\
\hline Total & 123 & 100,0 \\
\hline \multicolumn{3}{|l|}{ Occupation } \\
\hline Coach & 30 & 24,4 \\
\hline Sports Manager & 1 & 0,8 \\
\hline Self-Employment & 18 & 14,6 \\
\hline Educator & 3 & 2,4 \\
\hline Officer & 13 & 10,6 \\
\hline Dormitory Manager & 1 & 0,8 \\
\hline Business Manager & 1 & 0,8 \\
\hline Retired & 23 & 18,7 \\
\hline Quality Manager & 2 & 1,6 \\
\hline Artisan & 13 & 10,6 \\
\hline Accountant & 3 & 2,4 \\
\hline Worker & 10 & 8,1 \\
\hline Operating Manufacturer & 3 & 2,4 \\
\hline Certified Public Accountant & 1 & 0,8 \\
\hline Sailor & 1 & 0,8 \\
\hline Total & 123 & 100,0 \\
\hline \multicolumn{3}{|l|}{ Educational Background } \\
\hline Primary School & 8 & 6,5 \\
\hline Secondary School & 27 & 22,0 \\
\hline High School & 55 & 44,7 \\
\hline Associate Degree & 7 & 5,7 \\
\hline Bachelor's Degree & 25 & 20,3 \\
\hline Master's Degree & 1 & 0,8 \\
\hline Total & 123 & 100,0 \\
\hline
\end{tabular}

\subsection{Findings about Scale Questions}

The table below showing the responses of the amateur sports club managers to their quality systems.

Table 2. Findings about Scale Questions

\begin{tabular}{|l|r|r|}
\hline Questions & Frequency & Percentage \\
\hline $\begin{array}{l}\text { Implementation of strategic planning and goal setting activities in } \\
\text { club activities }\end{array}$ & & \\
\hline Not at all important & 9 & 7,3 \\
\hline Slightly important & 1 & 0,8 \\
\hline Neutral & 11 & 8,9 \\
\hline Important & 37 & 30,1 \\
\hline Extremely Important & 65 & 52,8 \\
\hline
\end{tabular}


Table 2. (continues)

Full and clear definition of the duties, powers and responsibilities of club employees

Not at all important

Slightly important

Neutral

Important

Extremely Important

Our club has a working environment that is satisfactory and increases productivity

Not at all important

Slightly important

Neutral

Important

Extremely Important

Supporting the participation of employees in the decision-making process within the limits that our managers require

Not at all important

Slightly important

Neutral

Important

Extremely Important

Solidarity, cooperation and team spirit among the staff in our club

Not at all important

Slightly important

Neutral

Important

Extremely Important

To have a competitive environment to enhance performance among employees in our club

Not at all important

Slightly important

Neutral

Important

Extremely Important

In-service training activities within the club are adequate

Not at all important

Slightly important

Neutral

Important

Extremely Important

Making our appreciation and rewarding with our clubs objective criteria

Not at all important

Slightly important

Neutral

Important

Extremely Important

Considering the domain information of the people to be selected for club management

Not at all important

Slightly important

Neutral

Important

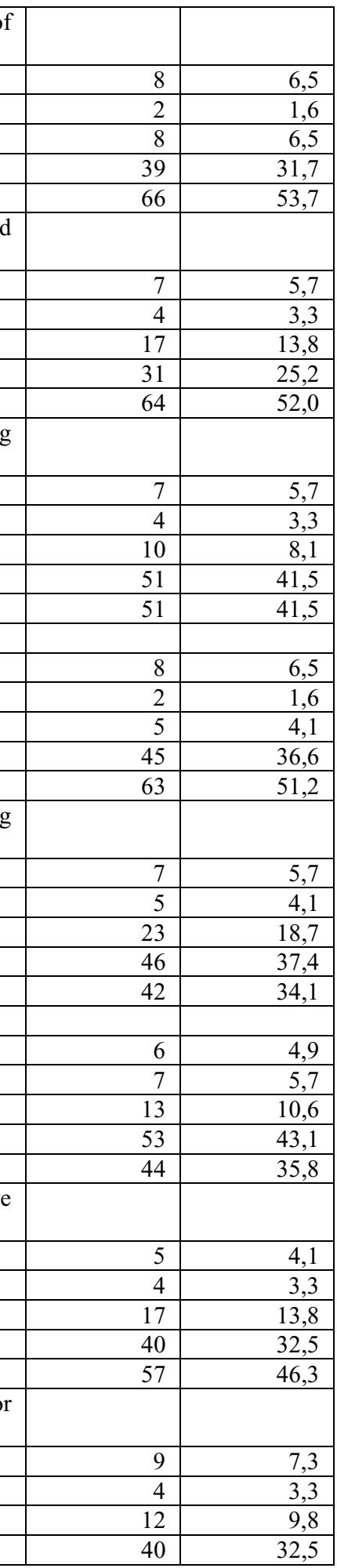


Table 2. (continues)

Extremely Important

Appraisal of the wishes and complaints of employees and supporters

in club management

Not at all important

Slightly important

Neutral

Important

Extremely Important

Having social facilities in our club

Not at all important

Slightly important

Neutral

Important

Extremely Important

Having a sports consultation center in our club structured

Not at all important

Slightly important

Neutral

Important

Extremely Important

The volunteer human resources information bank in our club

Not at all important

Slightly important

Neutral

Important

Extremely Important

Not at all important

Having official internet site

Not at all important

Slightly important

Neutral

Important

Extremely Important

The club management system includes sports and social work commissions for members outside the management board

\begin{tabular}{|l|r|r|}
\hline Not at all important & 7 & 5,7 \\
\hline Slightly important & 6 & 4,9 \\
\hline Neutral & 12 & 9,8 \\
\hline Important & 52 & 42,3 \\
\hline Extremely Important & 46 & 37,4 \\
\hline $\begin{array}{l}\text { Involving volunteers in management and organizational committees } \\
\text { in sportive competitions organized by our club }\end{array}$ & & \\
\hline Not at all important & 6 & 4,9 \\
\hline Slightly important & 6 & 4,9 \\
\hline Neutral & 19 & 15,4 \\
\hline Important & 48 & 39,0 \\
\hline Extremely Important & 44 & 35,8 \\
\hline $\begin{array}{l}\text { Having a knowledge bank where technical and administrative } \\
\text { information in our club }\end{array}$ & & \\
\hline Not at all important & 6 & 4,9 \\
\hline Slightly important & 5 & 4,1 \\
\hline Neutral & 15 & 12,2 \\
\hline Important & 46 & 37,4 \\
\hline
\end{tabular}


Table 2. (continues)

\begin{tabular}{|l|r|r|}
\hline Extremely Important & 51 & 41,5 \\
\hline $\begin{array}{l}\text { Providing coordination between departments regarding club } \\
\text { activities }\end{array}$ & 6 & \\
\hline Not at all important & 3 & 4,9 \\
\hline Slightly important & 20 & 2,4 \\
\hline Neutral & 45 & 36,3 \\
\hline Important & 49 & 36,6 \\
\hline Extremely Important & & \\
\hline Our club has library and internet service & 7 & 5,7 \\
\hline Not at all important & 6 & 4,9 \\
\hline Slightly important & 15 & 12,2 \\
\hline Neutral & 43 & 35,0 \\
\hline Important & 52 & 42,3 \\
\hline Extremely Important & & \\
\hline Having a sales center / store in our club which sells licensed \\
products of our club & & 14 \\
\hline Not at all important & 11 & 8,4 \\
\hline Slightly important & 27 & 22,0 \\
\hline Neutral & 30 & 24,4 \\
\hline Important & 41 & 33,3 \\
\hline Extremely Important & & \\
\hline Having club publications (newspaper, magazine, etc.) & 14 & 11,4 \\
\hline Not at all important & 7 & 5,7 \\
\hline Slightly important & 19 & 15,4 \\
\hline Neutral & 45 & 36,6 \\
\hline Important & 38 & 30,9 \\
\hline Extremely Important & & \\
\hline Revising and updating employees and departments' targets & 9 & 7,3 \\
\hline Not at all important & 3 & 2,4 \\
\hline Slightly important & 16 & 13,0 \\
\hline Neutral & 51 & 41,5 \\
\hline Important & 44 & 35,8 \\
\hline Extremely Important & & \\
\hline
\end{tabular}

It is seen that amateur club managers have positive perceptions of the factors related to the applicability of quality management systems when the responses given in the context of the question asked to measure the perceptions of the quality management processes of the amateur club managers are evaluated. In particular, managers seem to agree that the adoption of total quality understanding at the managerial level and the handling of the quality management system at the strategic level are very important. In this context,

$\mathrm{H}_{1}=$ the perception towards the practicality of total quality management is favorable in amateur sports clubs.

$\mathrm{H}_{1 \mathrm{a}}=$ the perception towards the practicality of total quality management is not favorable in amateur sports clubs. The $\mathrm{H}_{1}$ hypothesis is accepted. One of the other hypotheses established within the scope of the research;

$\mathrm{H}_{2}=$ the managers of the sports club do have sports background is an antecedent on the favorable perception towards the practicality of total quality management in amateur sports clubs.

$\mathrm{H}_{2 \mathrm{a}}=$ the managers of the sports club do have sports background is not an antecedent on the favorable perception towards the practicality of total quality management in amateur sports clubs. 
The following research findings are conducted for research hypotheses established to determine whether amateur sports club managers have individual amateur or professional sports backgrounds and if favorable perceptions for the implementation of quality management systems in sports clubs are antecedents.

Table 3. Sports Background - TQM Perception

\begin{tabular}{|c|c|c|c|c|}
\hline & \multicolumn{2}{|c|}{ Yes } & \multicolumn{2}{c|}{ No } \\
\hline & Mean & $\#$ & Mean & \# \\
\hline TQM_1 & 4,1942 & 103 & 4,25 & 20 \\
\hline TQM_2 & 4,233 & 103 & 4,3 & 20 \\
\hline TQM_3 & 4,1359 & 103 & 4,2 & 20 \\
\hline TQM_4 & 4,068 & 103 & 4,25 & 20 \\
\hline TQM_5 & 4,2816 & 103 & 4,05 & 20 \\
\hline TQM_6 & 3,8932 & 103 & 3,95 & 20 \\
\hline TQM_7 & 4 & 103 & 3,95 & 20 \\
\hline TQM_8 & 4,1359 & 103 & 4,15 & 20 \\
\hline TQM_9 & 4,1456 & 103 & 3,8 & 20 \\
\hline TQM_10 & 3,9903 & 103 & 3,95 & 20 \\
\hline TQM_11 & 4,1359 & 103 & 4 & 19 \\
\hline TQM_12 & 4,0097 & 103 & 4 & 20 \\
\hline TQM_13 & 3,7184 & 103 & 3,7895 & 20 \\
\hline TQM_14 & 4,1553 & 103 & 4 & 20 \\
\hline TQM_15 & 4,0388 & 103 & 3,85 & 20 \\
\hline TQM_16 & 3,9709 & 103 & 3,9 & 20 \\
\hline TQM_17 & 4,1068 & 103 & 3,85 & 20 \\
\hline TQM_18 & 4,0388 & 103 & 4,05 & 20 \\
\hline TQM_19 & 4,0583 & 103 & 3,9 & 20 \\
\hline TQM_20 & 3,5534 & 103 & 3,8 & 3,85 \\
\hline TQM_21 & 3,6699 & 103 & 3,9 & \\
\hline TQM_22 & 3,9709 & 103 & 3,9881591 & \\
\hline Mean & 4,0229455 & & & \\
\hline
\end{tabular}

When the perceptions of the quality management systems of the sports club managers who are amateur or professional sports background are evaluated, it is seen that the level of participation of the 20 managers who were not amateur or professional sports history before had an average of 3.99, while the quality of 103 managers who are amateur or professional sports history it is observed that the level of participation of the management systems in the sports clubs is higher by an average of 4.022. In this context, it is important to say that having a sport history is an influential factor in the variability and $\mathrm{H}_{2}$ hypothesis is accepted. table.

The research findings about the third hypothesis of the research are shown in the below

Table 4. Sports Management Education / TQM Education - TQM Perception

\begin{tabular}{|c|c|c|c|c|c|c|c|c|c|}
\hline \multicolumn{5}{|c|}{ Sports Management Education } & \multicolumn{5}{|c|}{ TQM Education - TQM Perception } \\
\hline & \multicolumn{2}{|c|}{ Yes } & \multicolumn{2}{|c|}{ No } & \multicolumn{3}{|c|}{ Yes } & \multicolumn{2}{|c|}{ No } \\
\hline & Mean & \# & Mean & \# & & Mean & \# & Mean & \# \\
\hline TQM_1 & 4,1923 & 52 & 4,2113 & 71 & TQM_1 & 4,1091 & 55 & 4,2794 & 68 \\
\hline TQM_2 & 4,0962 & 52 & 4,3521 & 71 & TQM_2 & 4,2 & 55 & 4,2794 & 68 \\
\hline TQM_3 & 4,1731 & 52 & 4,1268 & 71 & TQM_3 & 4,1273 & 55 & 4,1618 & 68 \\
\hline TQM_4 & 4,0577 & 52 & 4,1268 & 71 & TQM_4 & 4 & 55 & 4,1765 & 68 \\
\hline TQM_5 & 4,2115 & 52 & 4,2676 & 71 & TQM_5 & 4,1273 & 55 & 4,3382 & 68 \\
\hline TQM_6 & 3,9231 & 52 & 3,8873 & 71 & TQM_6 & 3,8909 & 55 & 3,9118 & 68 \\
\hline TQM_7 & 3,9808 & 52 & 4 & 71 & TQM_7 & 3,8727 & 55 & 4,0882 & 68 \\
\hline TQM_8 & 4,2115 & 52 & 4,0845 & 71 & TQM_8 & 4,1818 & 55 & 4,1029 & 68 \\
\hline TQM_9 & 4,0192 & 52 & 4,1408 & 71 & TQM_9 & 4,0364 & 55 & 4,1324 & 68 \\
\hline TQM_10 & 3,9808 & 52 & 3,9859 & 71 & TQM_10 & 4,0545 & 55 & 3,9265 & 68 \\
\hline TQM_11 & 4,1154 & 52 & 4,1127 & 71 & TQM_11 & 4,1455 & 55 & 4,0882 & 68 \\
\hline TQM_12 & 4,1154 & 52 & 3,9296 & 71 & TQM_12 & 4,1091 & 55 & 3,9265 & 68 \\
\hline
\end{tabular}


Table 4. (continues)

\begin{tabular}{|l|l|l|l|l|l|l|l|l|l|}
\hline TQM_13 & 3,6731 & 52 & 3,7714 & 70 & TQM_13 & 3,7818 & 55 & 3,6866 & 67 \\
\hline TQM_14 & 4,0962 & 52 & 4,1549 & 71 & TQM_14 & 4,1818 & 55 & 4,0882 & 68 \\
\hline TQM_15 & 4,0769 & 52 & 3,9577 & 71 & TQM_15 & 4,0182 & 55 & 4 & 68 \\
\hline TQM_16 & 3,8654 & 52 & 4,0282 & 71 & TQM_16 & 3,8909 & 55 & 4,0147 & 68 \\
\hline TQM_17 & 4,0385 & 52 & 4,0845 & 71 & TQM_17 & 4,0364 & 55 & 4,0882 & 68 \\
\hline TQM_18 & 3,9615 & 52 & 4,0986 & 71 & TQM_18 & 4 & 55 & 4,0735 & 68 \\
\hline TQM_19 & 4 & 52 & 4,0563 & 71 & TQM_19 & 4 & 55 & 4,0588 & 68 \\
\hline TQM_20 & 3,6731 & 52 & 3,5352 & 71 & TQM_20 & 3,5818 & 55 & 3,6029 & 68 \\
\hline TQM_21 & 3,6923 & 52 & 3,7042 & 71 & TQM_21 & 3,6182 & 55 & 3,7647 & 68 \\
\hline TQM_22 & 4 & 52 & 3,9296 & 71 & TQM_22 & 3,9273 & 55 & 3,9853 & 68 \\
\hline Mean & 4,007 & & 4,0248182 & & Mean & 3,9950455 & & 4,0352136 & \\
\hline
\end{tabular}

When the perceptions of the sports club administrators participating in the survey were evaluated in terms of their perception of sport management and quality management systems training, there was no significant difference between the averages and the averages of the responses of the two groups appeared to be parallel to each other. In this context $\mathrm{H}_{3}$ is accepted.

\section{Result}

In today's global world, the sport industry is considered as one of the most important industries and according to this consideration, it is important for the sports clubs, one of the most important actors in the sport industry, to protect the sustainability and success levels of this industry in terms of the clubs and the continuity of the industry. It is accepted as an important precondition for integrating quality and quality related processes into all processes of sports clubs at the point where successes such as success, profitability and productivity can be realized in this continuity and sports clubs. In other words, it is a must that every sports club that aims to maintain its sustainability within the sport industry and to ensure its profitability within the scope of sport aim and to maintain its assets should integrate continuous understanding of improvement within the club and total quality understanding into its systems. In this context, both the internal customers of the sports clubs, i.e. the employees, will be included in the maximal efficiency and processes, and the demands, needs and expectations of the target groups of the sports clubs addressing the massive target masses will be satisfied to the maximal level. The main argument in this framework is the need for sports clubs to implement quality management systems. Within the scope of the research carried out from this basic argument, a special evaluation was made on amateur sports clubs. The basic approach to evaluation is that the applicability of the quality management system in a sports club is a managerial decision and in this context the importance of the sports club managers is important. At the point of maintaining the quality management system as a strategic managerial approach, it is necessary for the individuals at the management level to make an effective effort to the applicability of the quality management systems and to establish the organization processes to serve the quality approach. In this context, the positive perceptions of the managers of the amateur sports club managers regarding the quality management systems are in parallel with the effective and efficient sustainability of the sports clubs' quality systems. Within the scope of the research, it has been concluded that amateur sports club managers have a positive perception of the implementation of quality management systems in sports clubs. Therefore, in amateur sports clubs it has become possible to establish quality management systems effectively and efficiently, to be sustainable as a strategic management process within the framework of total quality understanding. 


\section{References}

[1] M.Z. Seraslan, A. Kepeoğlu. Spor Örgütlerinde Toplam Kalite Yönetimi: Serkep Spor Isşletmesi Modeli (Morpa Kültür Yayınları, İstanbul, 2005).

[2] M. Tekin. Kalite Güvence ve Standartlar (Günay Ofset, Konya, 2007).

[3] S. Parlak. Toplam Kalite Yönetimi ve Kalite Yönetim Sistemi Standartlarl (Ekim Basım Yayın Dağıtım, Bura, 2013).

[4] T. Koçel, T. İşletme Yöneticiliği (Beta Yayıncılık, İstanbul, 2010).

[5] M. Çoruh. Sağlık Hizmetlerinde Toplam Kalite Yönetimi ve Performans Ölçümü Sempozyumu (1996).

[6] S. Mehra, S. Ranganathan. Int. J. of Qul. And Relb. Mang. 25 (9) 913-927. (2008).

[7] P.D. Knop, J.V. Hoecke, D. Bosscher. (2004). Sprt. Mang. 7 67-71. (2004). 